\title{
Granulocytic sarcoma: a diagnosis to be considered in unusual lymphoma syndromes
}

\author{
J.L. Mansi' ${ }^{1}$ P.J. Selby', R.L. Carter ${ }^{3}$, R.L. Powles ${ }^{2}$ and T.J. McElwain ${ }^{2}$ \\ ${ }^{1}$ Ludwig Institute for Cancer Research (London Branch), St. George's Hospital, Tooting, London SW17, ${ }^{2}$ Section \\ of Medicine, and ${ }^{3}$ Department of Histopathology, Institute of Cancer Research, Royal Marsden Hospital, Downs \\ Road, Sutton, Surrey, UK.
}

\begin{abstract}
Summary: A series of 7 patients with granulocytic sarcoma is presented to illustrate its varied clinical picture. In particular, this condition may present with features which suggest a non-Hodgkin lymphoma. The diagnosis will only be made if a high index of suspicion is maintained and special histopathological methods are used. Granulocytic sarcoma should be treated like an acute myeloid leukaemia.
\end{abstract}

\section{Introduction}

Granulocytic sarcoma (chloroma) is a rare extramedullary tumour composed of primitive cells of the granulocytic series. It was first described by Burns in $1811^{1}$ and the name chloroma was used by King in $1853^{2}$ to emphasize the greenish colour often found in the tumour which fades on exposure to air.

The tumour occurs in a variety of clinical settings and is often difficult to diagnose. It is closely associated with acute myeloid leukaemia which may be present at the time of initial diagnosis of granulocytic sarcoma, or, less commonly, may develop later. ${ }^{3-6}$ When granulocytic sarcoma presents without evidence of acute antecedent or coexisting myeloid leukaemia the diagnosis may be overlooked.

The tumour is usually undifferentiated, making histological diagnosis difficult. However, certain techniques such as electron microscopy ${ }^{6}$ the chloroacetate esterase (CAE) stain and the immunohistological demonstration of lysozyme, an enzyme known to occur in the primary granules of monocytes and myeloid cells, ${ }^{7}$ have been used to facilitate the diagnosis.

We describe 7 patients who have been seen at the Royal Marsden Hospital over the past 5 years. All of them presented diagnostic difficulty, and several were initially diagnosed as having non-Hodgkin lymphomas. They were only diagnosed by special histological methods or when acute myeloid leukaemia subsequently developed. We have not included patients presenting with acute myeloid leukaemia in whom soft tissue tumours (granulocytic sarcomas) were found incidentally and presented no diagnostic or management problems.

Correspondence: P.J. Selby, M.D., M.R.C.P.

Accepted: 25 November 1986

\section{Patients}

The details of the 7 patients are summarized in Table I. Cases 3, 6 and 7 presented with syndromes clinically indistinguishable from non-Hodgkin lymphoma. Only one of the patients (case no. 7) had had a bone marrow examination done before attending the Royal Marsden Hospital and all of them had symptoms relating to their mass for between 2-7 months before the aspiration. In 3 cases (nos. 3, 4, 5) the finding of acute myeloid leukaemia prompted re-examination of the biopsy material with the use of the definitive CAE stain (Figure 1).

Although all the patients eventually died of their disease, patients who were treated with the regimens used for acute myeloid leukaemia had complete remissions lasting from 2-16 months (Table II). Those who were initially thought to have lymphomas and were treated as such did not have a period of remission.

\section{Discussion}

These cases illustrate the diverse presentations of granulocytic sarcoma and the extent to which they may mimic non-Hodgkin lymphoma. We cannot be certain that the outcome would have been better if all patients had been diagnosed immediately and treated with therapy appropriate for acute myeloid leukaemia. The survival of patients with granulocytic sarcoma is reported to be similar to that of patients with acute myeloid leukaemia in the absence of a tumour mass, ${ }^{8}$ and various reports of granulocytic sarcoma preceding acute leukaemia suggest that it is of prognostic importance to recognize the condition and start systemic treatment with appropriate leukaemia 
Table I Clinical, pathological and survival characteristics of patients

\begin{tabular}{|c|c|c|c|c|c|}
\hline $\begin{array}{l}\text { Patient } \\
\text { no. }\end{array}$ & $\begin{array}{l}\text { Age (years) } \\
\text { sex and } \\
\text { race }\end{array}$ & $\begin{array}{l}\text { Presenting } \\
\text { syndrome }\end{array}$ & $\begin{array}{l}\text { Initial histological } \\
\text { diagnosis at } R M H\end{array}$ & $\begin{array}{l}\text { Chloroacetate } \\
\text { esterase stain } \\
\text { on initial biopsy }\end{array}$ & $\begin{array}{l}\text { Diagnosis of } \\
\text { granulocytic sarcoma }\end{array}$ \\
\hline 1 & $\begin{array}{l}38 \mathrm{~F} \\
\text { African }\end{array}$ & $\begin{array}{l}\text { L. submandibular } \\
\text { and parasternal mass }\end{array}$ & $\begin{array}{l}\text { Granulocytic } \\
\text { sarcoma }\end{array}$ & Not done & $\begin{array}{l}\text { AML on lst marrow at } \\
\text { RMH }\end{array}$ \\
\hline 2 & $\begin{array}{l}53 \mathrm{M} \\
\text { Pakistan }\end{array}$ & $\begin{array}{l}\text { Mass } R \text {. upper } \\
\text { arm and mass at } \\
\text { porta hepatis }\end{array}$ & $\begin{array}{l}\text { Granulocytic } \\
\text { sarcoma }\end{array}$ & + & CAE \\
\hline 3 & $\begin{array}{l}25 \mathrm{M} \\
\text { Caucasian }\end{array}$ & $\begin{array}{l}\text { Small bowel } \\
\text { tumour causing } \\
\text { obstruction }\end{array}$ & $\begin{array}{l}\text { Poorly differentiated } \\
\text { lymphocytic lymphoma }\end{array}$ & + & $\begin{array}{l}\text { CAE and AML one month } \\
\text { after diagnosis }\end{array}$ \\
\hline 4 & $\begin{array}{l}38 \mathrm{M} \\
\text { Caucasian }\end{array}$ & $\begin{array}{l}\text { Bone pain with } \\
\text { deposits in ribs }\end{array}$ & Anaplastic carcinoma & + & $\begin{array}{l}\text { CAE and AML two } \\
\text { months after diagnosis }\end{array}$ \\
\hline 5 & $\begin{array}{l}8 \mathrm{M} \\
\text { Arab }\end{array}$ & $\begin{array}{l}\text { Bilateral orbital } \\
\text { infiltration }\end{array}$ & Granulocytic & + & $\begin{array}{l}\text { CAE and AML on lst } \\
\text { marrow at RMH }\end{array}$ \\
\hline 6 & $\begin{array}{l}26 \mathrm{M} \\
\text { Iranian }\end{array}$ & $\begin{array}{l}\text { Supraclavicular } \\
\text { and axillary nodes } \\
\text { Mediastinal mass }\end{array}$ & $\begin{array}{l}\text { Diffuse } \\
\text { histiocytic lymphoma }\end{array}$ & Not done & $\begin{array}{l}\text { AML three months after } \\
\text { diagnosis }\end{array}$ \\
\hline 7 & $\begin{array}{l}33 \mathrm{M} \\
\text { Caucasian }\end{array}$ & $\begin{array}{l}\text { Flu-like illness } \\
\text { L. supraclavicular } \\
\text { nodes }\end{array}$ & $\begin{array}{l}\text { Diffuse poorly } \\
\text { differentiated } \\
\text { lymphoma }\end{array}$ & - & $\begin{array}{l}\text { AML } 9 \text { months after } \\
\text { diagnosis }\end{array}$ \\
\hline $\mathrm{L}=$ left & & RMH & $\begin{array}{l}\text { cute myeloid leukaemia } \\
\text { Royal Marsden Hospita }\end{array}$ & & etate esterase \\
\hline
\end{tabular}

Table II Treatment and outcome

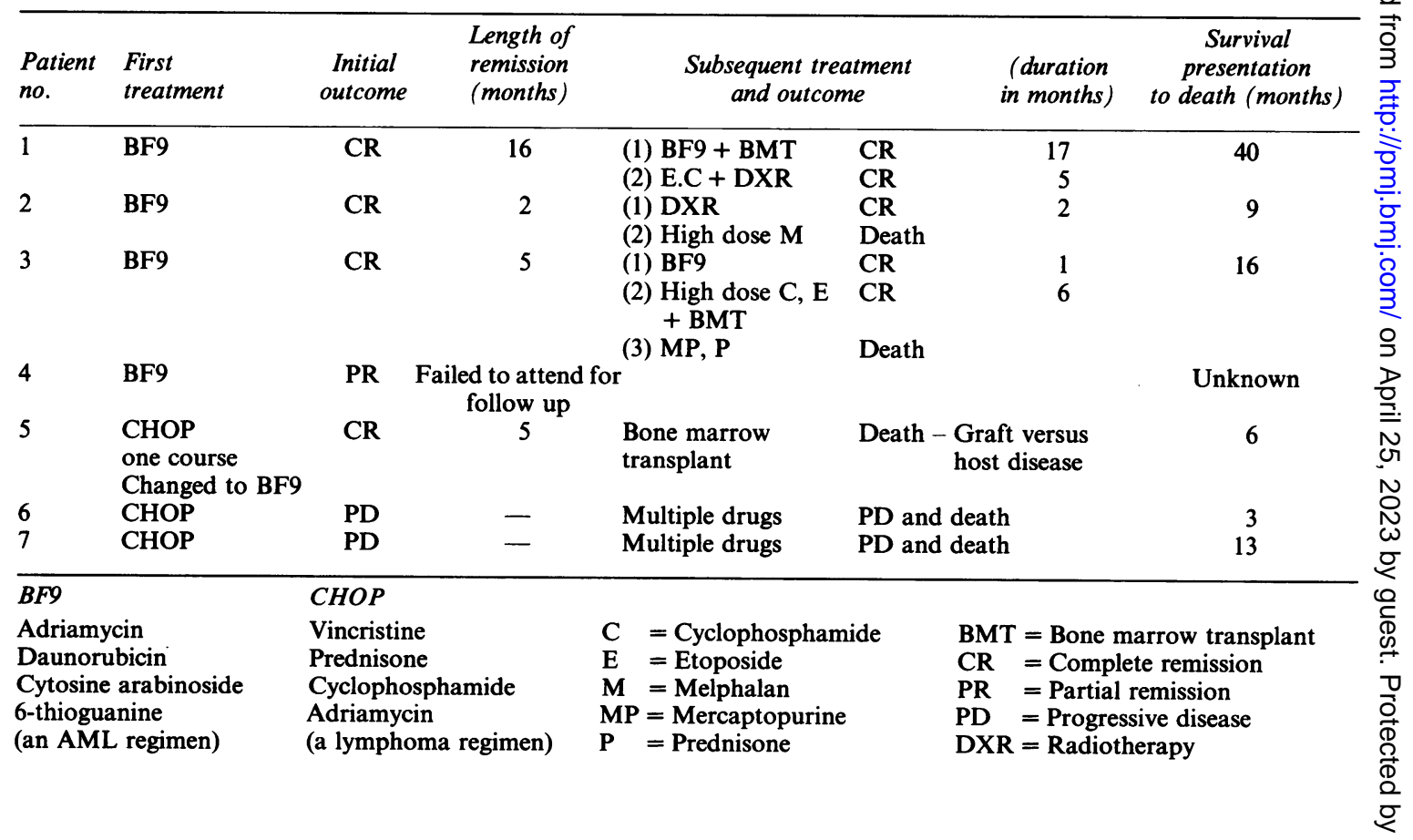




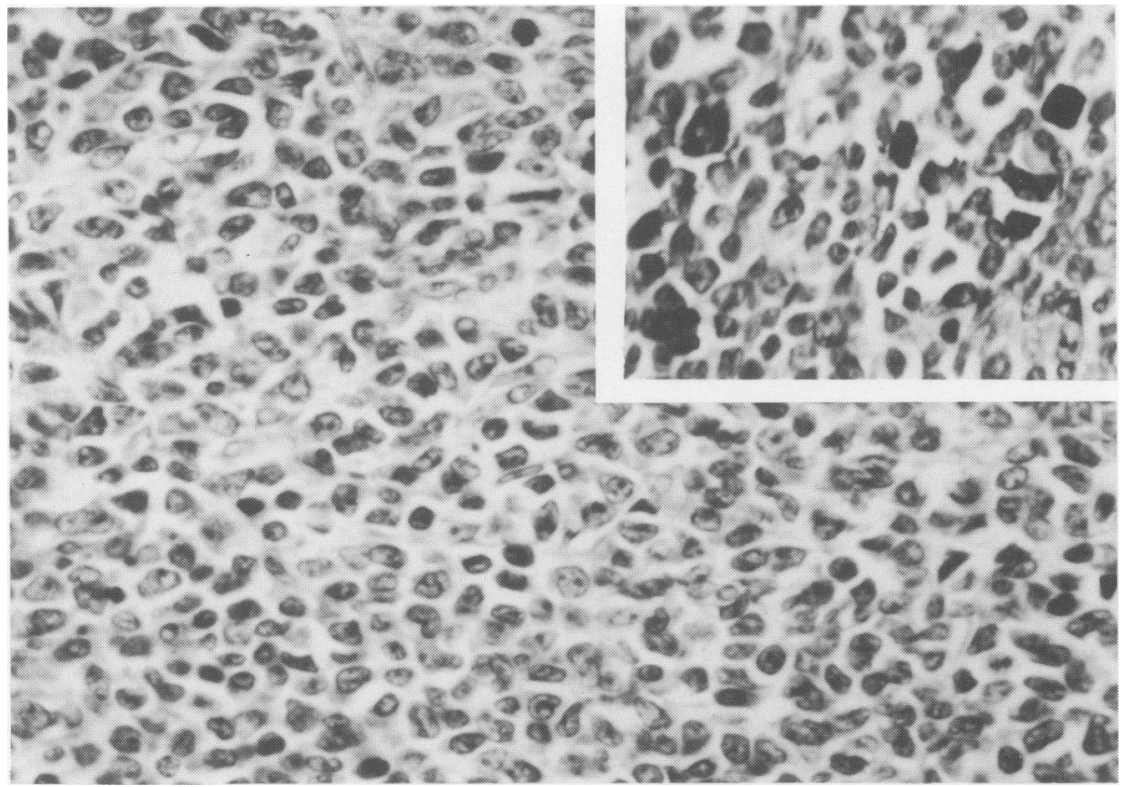

Figure 1 A lymph node replaced by granulocytic sarcoma. Normal structures are effaced by diffuse sheets of primitive myeloid cells with a high nucleocytoplasmic ratio and rather prominent nucleoli. There is no evidence of maturation in this example. The insert shows strong focal staining (black) of some primitive myeloid cells with chloroacetate esterase (CAE). Main illustration haematoxylin and eosin; both $\times 600$.

regimens if survival is to be increased..$^{6,7,9,10}$

The clinical and pathological diagnosis of granulocytic sarcoma continues to be a problem. It is essential to bear this condition in mind when confronted by problematic 'undifferentiated tumours' existing in soft tissues, bone or parenchymal organs. Bone marrow examination must be made and biopsy material stained with CAE. In addition, when doubt exists about the diagnosis of non-Hodgkin lymphoma
- particularly in cases which behave atypically, such as failure to remit on conventional chemotherapy - then the biopsy material should be re-examined for CAE positivity.

If a granulocytic sarcoma is diagnosed in the absence of leukaemia we suggest that treatment with an acute myeloid leukaemia regimen should be used and consideration be given to bone marrow transplantation in remission.

\section{References}

1. Burns, A. In: Observations of Surgical Anatomy. Head and Neck. Thomas Royce \& Co., Edinburgh, 1811, pp. 364-366.

2. King, A. A case of chloroma. Monthly Journal Medicine 1853, 17: 97.

3. Wiernik, P.H. \& Serpick, A.A. Granulocytic sarcoma (chloroma). Blood 1970, 35: 361-369.

4. Sears, H.F. \& Reid, J. Granulocytic sarcoma, local presentation of a systemic disease. Cancer 1976, 37: $1808-1813$

5. Krause, J.R. Granulocytic sarcoma preceding acute leukaemia. A report of six cases. Cancer 1979, 44: 10171021.

6. McCarty, Jr., K.S., Wortman, J.D., Daly J., Rundles, R.W. \& Hanker, J.S. Chloroma (granulocytic sarcoma) without evidence of leukaemia; facilitated light micros- copic diagnosis. Blood 1980, 56: 104-108.

7. Neiman, R.S., Barcos, M., Berard, C. et al. Granulocytic sarcoma: a clinicopathologic study of 61 biopsied cases. Cancer 1981, 48: 1426-1437.

8. Pinkus, G.S. \& Said, J.W. Profile of intracytoplasmic lysozyme in normal tissues, myeloproliferative disorders, hairy cell leukaemia, and other pathologic processes: an immunoparoxidase study of paraffin sections and smears. Am J Pathol 1977, 89: 351-366.

9. Beck, T.M., Day, J.C., Smith, C.E. \& Eddy, H.E. Granulocytic sarcoma treated as an acute leukemia. Report of a case. Cancer 1984, 53: $1764-1766$.

10. Eshghabadi, M., Majid Shojonia, A. \& Carr, I. Isolated granulocytic sarcoma: Report of a case and review of the literature. J Clin Oncol 1986, 4: 912-917. 